Demir, T. (2021). Türkçe öğretmenlerinin/öğreticilerinin pedagojik yeterlikleri üzerine bir değerlendirme. Ana Dili Eğitimi Dergisi, 9(3), 966-977.

Ana Dili Eğitimi Dergisi
Journal of Mother Tongue Education
www.anadiliegitimi.com
Geliş/Received: 07.04 .2021 Kabul/Accepted: 29.06 .2021
Araştırma Makalesi / Research Paper

\title{
Türkçe Öğretmenlerinin/Öğreticilerinin Eğitimi ve Pedagojik Yeterlikleri Üzerine Bir Değerlendirme*
}

\author{
Tarık DEMiR **
}

\begin{abstract}
Öz
Türkçe öğreticileri büyük oranda Türkçe ve Türk dili edebiyatı öğretmenliği bölümlerinde yetiştirilmektedir. Ana dili olarak Türkçe öğretmenleri bu bölümler aracılığıyla yetiştiriliyor olsa da Türkçe öğreticisi kavramı, öğretim faaliyetinin gösterildiği alanlar gözetilerek Türkçe eğitimi çatısı altında kollara ayrılmaktadır. Ana dili olarak Türkçe öğretmeni, ikinci/yabancı dil olarak Türkçe öğreticisi ve iki dillilere Türkçe öğreticisi olmak üzere üç kola ayrılabileceğimiz öğreticilerin, taşıması gereken pedagojik yeterliklerin de genel pedagoji bilgisiyle uyumlu biçimde ancak branşların gerekliliklerini de gözetecek şekilde düzenlenmesi gerekmektedir. Türkçe öğreticisinin yeterlikleri temelde ortak bilgi ve beceri alanları üzerinde tanımlanmış olsa da çağdaş yaklaşımlar yeterliklerin hem etkileşimli hem de alana özgü biçimde yorumlanarak işe koşulması gerektiği görüşündedir. Bu kapsamda Pedagojik Alan Bilgisi (PAB) ve yeterlikleri Türkçe öğreticileri özelinde ele alınacaktır. Çalışma kapsamında öğretici yeterlikleri incelenerek hedef kitle ve ortam üzerinden kollara ayrılan Türkçe öğreticilerinin faaliyet alanına göre eğitimlerinin nasıl çeşitlendirilebileceği üzerinde durulmuştur.
\end{abstract}

Anahtar Kelimeler: Türkçe, öğretmen, öğretici, yeterlik, pedagoji

\section{An Evaluation on the Education and Pedagogical Competencies of Turkish Teachers/Instructors}

\begin{abstract}
Turkish teachers are mostly trained in the Turkish and Turkish literature teacher education departments. Although they are trained as Turkish language teachers in those departments, the concept of Turkish instructor is further divided into categories under the umbrella of Turkish education, based on the contexts in which teaching takes place. The pedagogical competencies that instructors ${ }^{* * *}$, who may be classified into three categories as Turkish language, Turkish as a second/foreign language, and Turkish for bilingual students teachers, are to possess should be delineated per general pedagogical knowledge by also incorporating the specific requirements of fields of teaching. Although the competencies of Turkish teachers are mainly defined in terms of general knowledge and skills areas, in the contemporary approaches, competencies should be defined both generally and field-specifically. Accordingly, Pedagogical Field Knowledge (PFK) and competencies was discussed specifically for all types of Turkish instructors in this study. In addition, the training of different types of Turkish instructors, divided into categories based on target groups and teaching contexts, was scrutinized with the focus to determine how to diversify their training by examining instructor competencies in their respective fields of teaching.
\end{abstract}

Keywords: Turkish, teacher, instructor, competence, pedagogy

\footnotetext{
${ }^{*}$ Bu çalışma, yazarın Prof. Dr. Mustafa Durmuş danışmanlığında yaptığı doktora tezinden yararlanılarak hazırlanmıştır.

** Öğr. Gör., Gazi Üniversitesi, TÖMER, Ankara, tarikdemir@gazi.edu.tr, ORCID: orcid.org/ 0000-0002-41731948

*** Instructor, zorunlu olmayan eğitim kapsamında öğretim yapan kişi, öğreticiyi karşılamaktadır.
} 


\section{Giriş}

Öğretmen yeterlikleri, Millî Eğitim Bakanlığı tarafından ÖMGY (2017, s. 4), mesleğin etkin ve verimli bir şekilde icra edilebilmesi için sahip olunması gereken bilgi, beceri ve tutumlar olarak tanımlanmışır. Öğretmen/öğretici yeterlikleri, birçok sürece etki gücüne sahip olduğu için öğretmenlerin yetiştirilmesi, istihdam etme, değerlendirme ve geliştirme süreçlerinde tanımlanmış bu yeterlikler üzerinden hareket edilir. Alanyazında, öğretmen kavramı ana dili olarak Türkçe öğretenleri karşılarken Türkçeyi ikinci/yabancı dil olarak öğretenler için öğretici kavramı daha çok kullanılmaya başlanmıştır. Kavramlaştırmaya da yansıyan bu branşlaşmanın öğretici yeterliklerinin yorumlanması ve düzenlenmesinde de gözetilmesi gerektiği düşünülmektedir.

Öğretmen bilgisiyle ilgili araştırmaların öncüsü olan Shulman (1987, s. 8), bir öğretmenin sahip olması gereken asgari bilgi türlerini;

- alan bilgisi

- genel pedagoji bilgisi

- öğretim programı bilgisi

- öğrenen özellikleri hakkında bilgi

- eğitim ortamı ve şartları bilgisi

- eğitim hedefleri, amaçları ile bunların felsefi ve tarihi temelleri bilgisi

- pedagojik alan bilgisi olarak yedi başlık altında açıklamıştır. Bu bilgi türleri aynı zamanda öğretmenlerin/öğreticilerin taşıması gereken yeterliklerinde sınırını çizmektedir. Bunlardan süreçte en yoğun kullanılan bilgi türü pedagoji ve pedagoji ile alan bilgisinin kesişiminden doğan pedagojik içerik/alan bilgisidir.

Pedagoji bilgisi Koehler ve Mishra (2005) 'ya göre öğretmenlik mesleğinin bilgi alanlarının birleşimidir ve bu bilgi sayesinde öğrenen profilleri ve özellikleri dikkate alınarak öğretim süreçleri planlanır, yürütülür ve değerlendirilerek döngüsel gelişimi sağlanır.

Pedagojik içerik bilgisi, öğretmenlere özgü bir tür bilgidir ve öğretmenlerin pedagojik bilgilerini (öğretme hakkında bildiklerini) konu bilgilerine (öğrettikleri hakkında bildiklerini) ilişkilendirme biçimine dayanır. Öğretmenlerin pedagojik bilgilerinin ve pedagojik içerik bilgisini içeren konu bilgilerinin entegrasyonu veya sentezidir (Shulman, 1986. s. 1).

Öğreticilerin hedef dil konumunda sundukları dilin öğreniciler tarafından başarılı biçimde öğrenilmesi ve edinilmesi öğreticilerin tutum, yaklaşım ve davranışlarına bağlıdır. Bu tutum, yaklaşım ve davranışlar ise öğreticilerin teknoloji, pedagoji ve alan bilgilerinin gelişmişliğinin yanı sıra bunları işe koşabilme yeterlikleri ile doğru orantılıdır. Öğreticilerin sahip olması gereken bu yeterliliklerin başında şüphesiz alan bilgisi gelir. Hedef dile ait alan bilgisinin aktarımında kullanılacak araçlar günümüzde eğitim sürecine teknolojiyi olmazsa olmaz bir bileşen olarak dâhil etmektedir. Ancak önemi tartışımaz bu bilgilerin öğreniciye nasıl aktarılacağı ise yukarıda ifade edilen yeterlik alanlarının tamamını etkileyen bir güce ve öneme sahiptir. Öğretim sürecinde sorulması ve hassasiyetle cevaplanması gereken "Nasıl?" sorusunun cevabı, etkin alanı yani pedagojiyi oluşturmaktadır. Ana dil eğitiminde veya ikinci/yabancı dil olarak öğretilen başat dillere ilişkin alanlarda özel bir uzmanlık konusu olarak çalışılan pedagoji başlı̆ı ikinci/yabancı dil olarak Türkçe öğretiminde henüz yeterince çalışımamıştır. Nitekim yabancı veya ikinci dil öğretiminde öğreticilerin pedagojik yeterlikleri hatta bu alanda pedagojiye yönelik yapılan lisansüstü çalışma sayısı yok denecek kadar azdır.

Öğrenme-öğretme süreci Shulman (1986)'ın geliştirdiği yaklaşımla alan-pedagoji kesişimine odaklanmış sonrasındaki çalışmalar ve çağın gereklilikleri ile teknolojiyi de sürece dâhil etmiştir. Bunun başında Mishra ve Koehler (2006) gelir. Böylelikle eğitim dünyası Teknolojik Pedagojik Alan Bilgisi tanımına kavuşmuştur. Söz konusu kavramların ulusal bir standart oluşturulması noktasında MEB Öğretmen Yetiştirme ve Eğitimi Genel Müdürlüğü uhdesinde yürütülen Temel Eğitimi Destekleme Projesi kapsamında yayınlanan Öğretmenlik Mesleği Genel Yeterlikleri adlı çalışma önem arz etmektedir. Alanyazındaki birçok çalışmanın etkisinde ve yukarıda bahsi geçen çalışmalar ışığında MEB ve YÖK Öğretmenlik Mesleği Genel Yeterlikleri üzerine çalışmalar yürütmeye devam etmiş ve MEB (2011) tarafından Öğretmenlik Mesleği Genel Yeterlikleri güncellenerek tekrar yayınlanmış, 
eğitim fakültelerindeki ilgili programlar bu şekilde güncellenmiştir. Bu çalışmalar devam ederken Türk Eğitim Derneği (2009) tarafından da Öğretici Yeterlikleri adlı bir çalışma kitaplaştırılmıştır.

Öğretmen yeterliği eğitim sistemimin temel konularından birinin teşkil etmektedir. Çünkü eğitimin hedeflenen amaçlara ulaşması öğretmenlerin sahip oldukları yeterlikle yakından ilgilidir (Temizyürek ve Aksoy, 2016, s. 103).

Çalışma kapsamında alanyazından elde edilen bilgiler ışığında evrensel ve ulusal ölçütler, çalışmalar incelenerek aşağıdaki sorular cevaplanmaya çalışılmıştır:

1. Türkçe öğretmenlerinin/öğreticilerinin taşıması gereken pedagojik yeterlikler nelerdir?

2. Pedagojik yeterlikler nerede, ne zaman ve nasıl kazandırılmalıdır?

\section{Yöntem}

Doküman analizine dayalı araştırmada sorulara yanıt bulabilmek amacıyla alanyazın taraması yapılmış ve ulusal ve uluslararası alanyazında ilgili çalışmalardan yararlanılarak Türkçe öğretmenleri ve öğreticilerinin yeterliliklerine dair kuramsal bulgular araştırmacı tarafından sentezlenerek doğrudan raporlaştırmaya gidilmiştir.

\section{Araştırma ve Yayın Etiği}

Bu çalışmada "Yükseköğretim Kurumları Bilimsel Araştırma ve Yayın Etiği Yönergesi" kapsamında uyulması belirtilen tüm kurallara uyulmuştur. Yönergenin ikinci bölümü olan "Bilimsel Araştırma ve Yayın Etiğine Aykırı Eylemler" başlığı altında belirtilen eylemlerden hiçbiri gerçekleştirilmemiştir.

\section{Bulgular}

Alanyazın incelendiğinde öğretmen yetiştirme ve öğretici yeterlikleri ile ilgili çalışmalarda öğreticilerin taşıması gereken yeterlikler bilgi alanlarına ayrılmıştır ancak bu alanların ayrı ayrı düşünülmemesi gerektiği vurgulanmaktadır. Farklı zamanlarda farklı yerlerde hatta farklı dil öğreticileri üzerinde yapılan çalışmalara bakıldığında bilgi türleri ve yeterlik alanları çok büyük oranda benzeşim göstermektedir. Shulman (1986, 1987), Mishra ve Kohler (2006), Richards (2008, 2009, 2011); TED (2009), MEB (2017), Hacettepe (2017), YÖK (2018) ve TYYÇ (2020) kaynaklarına bakıldığında birbirinin gelişimini de etkileyen bu çalışmalarda öğretici yeterliklerindeki ortaklıklar görülebilecektir. Bu durumun bir diğer yansıması MEB'in öğretmenler için oluşturduğu özel alan yeterlikleri dosyalarına bakıldığında da görülebilir. Branşlara göre alt bileşenler disiplin alanına göre değişmekle birlikte yeterlik alanları ve yeterlik tanımlamaları büyük oranda doğal olarak benzeşmektedir. Bu yüzden Türkçe öğreticileri için yapılacak yeterlik çalışmalarında ulusal ve uluslararası alanyazından faydalanılabileceği düşünülmektedir.

British Council tarafından yayınlanan CPD $(2015$, s. 6) adlı dosyada gelişimin boyutlarını görselleştirerek aktardığı dosyada öğreticinin sınıf içi süreçlerdeki kaliteyi artırmak amacıyla yapması gerekenlere yer verilmiştir. Gelişimin aşamaları temsil eden dört boyutta çevreden merkeze doğru ilerlemesi ve gelişimi beklenen 12 yeterlik bulunmaktadır. Bu yeterlikler şunlardır:

- Dersleri ve kursları planlamak

- Öğrencileri anlamak

- Dersi yönetmek

- Konuyu bilmek

- Kaynakları yönetmek

- Öğrenmeyi değerlendirmek

- BIT (Bilgi İletişim Teknolojileri) entegrasyonu

- Mesleki gelişim için sorumluluk almak

- Kapsayıcı uygulamaları kullanmak

- Çok dilli yaklaşımları kullanmak

-21. yüzyıl becerilerini geliştirmek

- Eğitim politikalarını ve uygulamalarını anlamak. Bu sayılan yeterlikler ilgili çalışmaların hemen hepsinde yer almaktadır ancak önemli olan bu bilgilerin eyleme dökülebilmesidir. 
Hizmet öncesi ve hizmet içi eğitimler planlanırken planlamanın sadece akademik ve teorik olmaması gerektiğini vurgulayan TED $(2009$, s. xxi)'e göre, süreç planlanırken uygulama boyutunun göz ardı edilmemesi gerekir ve hizmet öncesi, hizmet içi eğitimin sürekli mesleki gelişim anlayışı ile bir bütün hâlinde planlanmalıdır. Öyle ki bu bütünlük sağlanmadığı sürece öğretici yeterliklerinin geliştirilmesinin mümkün olmadığı vurgulanır. Buradan hareketle öğretici yeterlilikleri üzerine yapılan çalışmalar sadece lisans düzeyinde kazandırılan yeterlilikler çerçevesinde düşünülmemeli ve sürekli, hayat boyu ve sargın eğitim kapsamında devamlılı̆ı olan bir bütünlükte kurgulanmalı ve uygulanmalıdır denilebilir.

Türkiye Yükseköğretim Yeterlikler Çerçevesi (TYYÇ, 2020) sayesinde 22 temel alana yönelik yeterlilikler hazırlanmıştır. Bunlar arasında Öğretmen Yetiştirme ve Eğitim Bilimleri Temel Alanı da bulunmaktadır. Söz konusu çalışmada öğretmen yetiştirmenin ve eğitim bilimlerinin kapsamının çok geniş olduğu ve birey ile toplumun isteklerinin, ihtiyaçlarının karşılanması, bütünleştirilmesi gerektiği ifade edilmiştir. TYYÇ’ye göre söz konusu eğitim bilimleri, öğretmen yetiştirme olduğunda konunun çok alanlı (multidisciplinary), karma-alanlı (cross-disciplinary) ve alanlarüstü (transdisciplinary) yaklaşımla ele alınması gerekir. Çünkü alan olarak öğretmenlik ve bu mesleğin temsilcisi olarak öğretmen; bilim, sanat ve öğretimi bütüncül yapıda sunan, sunması gerekendir. Kuram ve uygulamayı birleştirendir. Tüm bu bütünleştirme ve bağdaştırmayı yapabilmek ise eğitim bilimlerinin yani pedagojinin konusudur. Bu yüzden öğretmen yetiştirme süreçleri eğitim bilimlerinden, pedagojiden ayrı ele alınamaz. Bir diğer ifadeyle pedagoji eğitimi almamış bir eğitimci düşünülemez.

MEB ÖMGY $(2017$, s. 7)'de belirtilene göre öğretici yeterlikleri belirlenirken Avrupa Birliği ülkeleriyle uyum arz edecek yapıda olması hedeflenmiştir. Bu amaçla çalışmada hem Türkiye'den hem de yurt dışından birçok uzman, öğretmen ve akademisyen yer almıştır. Bu ekiplerle yapılan çalıştaylar ve neticede ortaya çıkan ürünlerin sınanması ile 233 performans göstergesi, 31 alt yeterlikten oluşacak biçimde "Öğretmenlik Mesleği Genel Yeterlikleri" yayınlanmıştır. Bunlar: "Kişisel ve mesleki değerler-mesleki gelişim", "Öğrenciyi tanıma", "Öğrenme ve öğretme süreci", "Öğrenmeyi, gelişimi izleme ve değerlendirme", "Okul, aile ve toplum ilişkileri" ile "Program ve içerik bilgisi" olarak altı ana başıkta toplanmıştır.

Bu yeterlilikler Tablo 1'de sunulmuştur:

Tablo 1.

Öğretmenlik Mesleği Genel Yeterlikleri

\begin{tabular}{|c|c|c|}
\hline A Mesleki Bilgi & B Mesleki Beceri & C Tutum ve Değerler \\
\hline A1. Alan Bilgisi & B1. Eğitim Öğretimi Planlama & $\begin{array}{l}\text { C1. Millî, Manevi ve Evrensel } \\
\text { Değerler }\end{array}$ \\
\hline $\begin{array}{l}\text { Alanında sorgulayıcı } \\
\text { bakış açısını kapsayacak } \\
\text { şekilde ileri düzeyde } \\
\text { kuramsal, metodolojik ve } \\
\text { olgusal bilgiye sahiptir. }\end{array}$ & $\begin{array}{l}\text { Eğitim öğretim } \\
\text { süreçlerini etkin bir } \\
\text { şekilde planlar. }\end{array}$ & $\begin{array}{l}\text { Millî, manevi ve evrensel } \\
\text { değerleri gözetir. }\end{array}$ \\
\hline A2. Alan Eğitimi Bilgisi & $\begin{array}{l}\text { B2. Öğrenme Ortamları } \\
\text { Oluşturma }\end{array}$ & C2. Öğrenciye Yaklaşım \\
\hline $\begin{array}{l}\text { Alanının öğretim } \\
\text { programına ve pedagojik } \\
\text { alan bilgisine hâkimdir. }\end{array}$ & $\begin{array}{l}\text { Bütün öğrenciler için } \\
\text { etkili öğrenmenin } \\
\text { gerçekleşebileceği } \\
\text { sağlıklı ve güvenli } \\
\text { öğrenme ortamları ile } \\
\text { uygun öğretim } \\
\text { materyalleri hazırlar. }\end{array}$ & $\begin{array}{l}\text { Öğrencilerin gelişimini } \\
\text { destekleyici tutum } \\
\text { sergiler. }\end{array}$ \\
\hline A3. Mevzuat Bilgisi & $\begin{array}{l}\text { B3. Öğretme ve Öğrenme } \\
\text { Sürecini Yönetme }\end{array}$ & C3. İletişim ve İş Birliği \\
\hline
\end{tabular}




\begin{tabular}{|c|c|c|}
\hline \multirow{3}{*}{$\begin{array}{l}\text { Birey ve öğretmen olarak } \\
\text { görev, hak ve } \\
\text { sorumluluklarına ilişkin } \\
\text { mevzuata uygun } \\
\text { davranır. }\end{array}$} & $\begin{array}{c}\text { Öğretme ve öğrenme } \\
\text { sürecini etkili bir şekilde } \\
\text { yürütür. }\end{array}$ & $\begin{array}{l}\text { Öğrenci, meslektaş, aile } \\
\text { ve eğitimin diğer } \\
\text { paydaşları ile etkili } \\
\text { iletişim ve iş birliği kurar. }\end{array}$ \\
\hline & B4. Ölçme ve Değerlendirme & C4. Kişisel ve Mesleki Gelişim \\
\hline & $\begin{array}{c}\text { Ölçme ve değerlendirme, } \\
\text { yöntem, teknik ve } \\
\text { araçlarını amacına uygun } \\
\text { kullanır. }\end{array}$ & $\begin{array}{l}\text { Öz değerlendirme } \\
\text { yaparak, kişisel ve } \\
\text { mesleki gelişimine } \\
\text { yönelik çalışmalara } \\
\text { katılır. }\end{array}$ \\
\hline
\end{tabular}

Herkes İçin Kaliteli Eğitimciler projesi kapsamında Oxfam Novib ve Uluslararası Eğitim adlı federasyon tarafından yayınlanan raporda öğretici yeterliklerinin benzerlik ve farklııkları incelenerek uluslarararası ortak bir zemin olup olmadığı araştırılmıştır. Öğretmenler üzerinde yapılan çalışma sonucunda yayınlanan bu rapor Güney Afrika, Yeni Zelanda, Kanada; Şili, Brezilya; Hindistan, Malezya; Hollanda ve Slovenya ile pilot uygulama kapsamında Mali ve Uganda ülkelerinden veriler içermektedir. Söz konusu dokümanda öğretmen eğitiminde çeşitli uygulamaların benimsendiği Hollanda'da farklı sürede ve farklı kurumlarda eğitim alarak yetiştirilmelerine rağmen bütün öğretmenlerin sahip olması beklenen yedi ana yeterlik alanı paylaşılmışır. Hollanda Parlamentosu tarafından 2004 yılında yürürlüğe konan "eğitim sektöründe çalışanlar" adlı yasayla şu şekilde belirlenen yeterlikler şunlardır:

1. Kişilerarası yeterlik: Öğretmen kendi davranışlarının ve bu davranışlarının öğrenciler üzerindeki etkisinin farkındadır. Grup çalışmalarında iletişimi sağlama konusunda yeterli bilgi ve becerilere sahiptir.

2. Pedagojik yeterlik: Öğretmen her bir öğrenci ve sınıfın tamamını düşünerek güvenilir öğrenme ortamı oluşturmak için gerekli pedagojik bilgi ve becerilere sahiptir.

3. Alan ve yöntem bilgisi yeterliği: Öğretmen konu alanında yeterli bilgi ve becerilere sahiptir ve etkili bir öğrenme ortamı oluşturmak için hangi öğretim yöntemlerini kullanması gerektiğini bilir.

4. Organizasyonel yeterlik: Öğretmen derslerde ve sınıf içinde iyi bir öğrenme ve çalışma ortamı oluşturabilmek için gerekli bilgi ve becerilere sahiptir.

5. Meslektaşlarıyla iş birliği yapma yeterliği: Öğretmen iş ilişkileri ve okul yönetiminin yanı sıra okulundaki olumlu öğretim ortamına katkıda bulunacak bilgi ve becerilere sahiptir.

6. Çalışma ortamıyla iş birliği yapma yeterliği: Öğretmen öğrencilere yardım yapan ya da okulun anlaşmalı olduğu kurum ve kişilerle iyi bir iş birliği kurma konusunda yeterli bilgi ve beceriye sahiptir.

7. Yansıtıcı olma ve gelişim yeterliği: Öğretmen mesleği ve yeterlikleri hakkındaki görüşlerini değerlendirir, geliştirir, başkalarıyla paylaşır (Bourgonje ve Tromp, 2011, s. 104-105).

İngiltere ve İskoçya'da ise genel öğretmen konseyi ve Yeni Zelanda'da Öğretmenler Konseyi tarafından oluşturulan standartlar da bulunmaktadır. ABD'de ise NCATE ve TAEC tarafından belirlenen standartlar CAEP (Council for the Accreditation for Education Preparators) öğretmen yetiştiren kurumların akreditasyonu konseyi tarafından tek çatı altında toplanmıştır: Alan bilgisi, pedagojik bilgi, öğretim becerileri ve öğretmenliğin doğasına ilişkin yönleri vurgulayan bu standartlar altı madde altında toplanmıştır. Birincisi dil, dil bilim ve karşılaştırmalı çalışmalardır. i̇kincisi kültür, edebiyat ve disiplinlerarası kavramlarıdır. Üçüncüsü dil edinimi kuramları ve öğretim uygulamalarıdır. Dördüncü program ve eğitim uygulamalarıyla standartların bütünleştirilmesi iken beşincisi ölçme değerlendirmedir. Altıncı madde ise profesyonellik olarak tanımlanmıştır (Güleç ve Okur; Karahan, 2015, s. 23).

Bu açıklamalardan hareketle Türkçe öğretmeninin/öğreticilerinin pedagojik yeterlilikleri sorunsalı ayrıntılı olarak aşağıdaki bölümlerde tartışımıştır. 


\section{Türkçe Öğretmenlerinin/Öğreticilerinin Taşıması Gereken Pedagojik Yeterlikler Nelerdir?}

Incelenen temel başvuru kaynakları ve literatür kapsamında MEB Öğretmen Mesleği Genel Yeterlikleri (2017), TED Öğretmen Yeterlikleri (2009) ve Shulman (1986)'ın öğretmen yeterliklerine ilişkin tanımlamaları ışığında sahadaki araştırma ve uygulamalardan edinilen bilgiler birleştirilerek aşağıdaki yeterlik listesi oluşturulmuştur. Oluşturan yeterlik listesi aşağıda paylaşılmıştır. Aşağıdaki kırk maddelik yeterlik listesi Türkçe öğretmen ve öğreticilerinin farklı kültürlerden gelen öğrencilerin bulunduğu sınıflarda sahip olması gereken pedagojik yeterlikler listesi alan ve teknoloji bilgisi ile uyumlu biçimde geliştirilmiştir. İkinci/yabancı dil olarak Türkçe öğreticileri odaklı geliştirilen listenin ana dili olarak Türkçe öğretmenleri için de geçerlik arz ettiği düşünülmektedir çünkü bu sınıflar da özellikle mülteciler varsa çok kültürlü bir ortam oluşmaktadır.

Bugün Türkiye'de doğan mülteci çocukların ana dili olarak Türkçe öğretilen sınıflarda Türkiye vatandaşı olarak eğitim-öğretim hayatına başladığını ancak ana dilinin Türkçe ve kaynak kültürün Türk kültürü olmadığı düşünüldüğünde bu çalışmanın ana dili olarak Türkçe öğretimi için de en az ikinci/yabancı dil öğretimi kadar önem arz ettiği anlaşılacaktır.

1. Derslerimi bireysel farklılıkları dikkate alan bir biçimde gerçekleştirebilme

2. Sınıftaki herkese, eşit öğrenme fırsatları sunabilme

3. Etkili iletişim kurulabilen demokratik öğrenme ortamları hazırlayabilme

4. Öğrenicilerin üst düzey bilişsel becerilerini geliştirecek ortamlar oluşturabilme

5. Öğrenicilerin dikkatini öğrenecekleri konuya çekecek yöntem ve tekniklerden yararlanabilme

6. Öğrenicilerin sorgulayarak öğrenmesini sağlayabilme

7. Ders, planlamamdan önce bittiğinde dersi doğal biçimde devam ettirebilme

8. Öğretim esnasında yaşanabilecek sorunlarla/krizlerle başa çıkabilme

9. Ders esnasındaki değişkenlere (gelen sorular, oluşan durumlar vb.) göre öğretilenleri anında yeniden yapılandırabilme

10. Öğretilen konuya ilişkin geliştirdiği taktikleri kullanabilme

11. Derslerde öğretim teknolojilerinden etkin biçimde yararlanabilme

12. Öğretim sürecinde içerikle ilgili motivasyonu artıracak etkinlikleri (şarkı, şiir, tekerleme, kısa film vb.) kullanabilme

13. Öğrenicilerin zorlandığı içerikler karşısında etkin çözümler üretebilme

14. Öğrenicilerin öğrenmeye engel oluşturan tutumlarına karşı etkili çözümler sunabilme

15. Ders esnasında öğrenicilerimin performanslarını gözlemleyebilme

16. Öğrenicilerin öğrenme stratejilerini gözlemleyebilme

17. Öğrenicilerin portfolyosunu tutabilme

18. Öğretim esnasında materyal ve hazırlıklar dışında örnekler sunabilme

19. Anlatımların hızını ve içerik bileşenlerinin (açıklama, örnek vb.) seçimini öğrenicilerin seviyesine göre ayarlayabilme

20. Derste kullanacağım örnek vb. içerikleri öğrenicilerin hayatlarına uygun seçebilme

21. Dersi, her aşamasını uyumlu bir bütün halinde planlayıp değişkenlere rağmen yürütebilme

22. Sınıf içi ölçme ve değerlendirme tekniklerini/araçlarını kullanabilme

23. Öğrenicilerin gelişimlerini destekleyecek dönütler verebilme

24. Farklı kültürlere karşı hoş görülü bir tutum sergileyebilme

25. Ifade, davranış ve tutumları yerel (kaynak) kültürlerdeki tutum ve davranış farklııılarına göre düzenleyebilme

26. Yerel (kaynak) kültür ve bileşenleri sınıf ortamına taşındığında fark edebilme

27. Öğrencileri rahatsız etmeyecek ifadeleri seçerek kullanabilme

28. Öğrenicilerin yaşadıkları ve yaşayabilecekleri kültürel şokları atlatabilmeleri için onlara destek olabilme

29. Dersi öğrenicileri motive edecek olumlu bir duruş ve tutumla başlatıp sürdürebilme

30. Öğrenicileri öğrenmeye karşı isteklendirecek konuşmalar/sunumlar yapabilme

31. Öğrencilerin başarılı olabileceğine olan inancımı her şartta koruyabilme

32. Öğrenicilerin hatalarına karşı sabır gösterebilme

33. Aynı soruyu defalarca cevaplasam bile öğrenicilere tepki geliştirmeden cevap verebilme 
34. Öğrenicilerin, her bakımdan, güvenini kazanabilme

35. Öğrenicilerimle iletişim çatışmalarımı engelleyebilme

36. Öğrenme güçlüğü veya davranış problemi olan öğrenicilerin kontrollü biçimde uyum sağlamalarına yardımcı olabilme

37. Disiplin problemleri ile kolaylıkla baş edebilme

38. Gerektiğinde meslektaşlardan ve idarecilerden destek isteyebilme

39. Öğrenicilerin ön yargılarını (akademik yetenek, kültürel etkileşim vb.) fark edip üstesinden gelebilme

40. Öğrenicileri rahatsız edecek (sınıflayıcı, ayırt edici, ötekileştirici vb.) ifadeleri kullanmamak için özen gösterebilme

\section{Pedagojik Yeterlikler Nerede, Ne Zaman ve Nasıl Kazandırılmalıdır?}

Mete ve Asar (2014, s. 139), Türkçenin yabancı dil olarak öğretimi alanına personel yetiştiren en önemli bölüm olarak Türkçe bölümlerini işaret etmektedir. Bu ifadenin gerekçesi ise bölüm programlarının ana dili olarak Türkçe öğretecek kişileri yetiştirme temel amacının yanı sıra Türkçenin yabancı dil olarak öğretimine yönelik derslerle de yapılandırılmış olmasıdır. Ancak araştırmacılar bunun yeterli olmadığını kısıtlı sürede verilen bu derslerin sadece farkındalık yaratacağını ve Türkçenin yabancı dil olarak öğretimini yapacak kişilerin eğitimini ayrı bir alan olarak görmek gerektiğini ifade etmektedirler. Ayrıca bu yapılandırmada teoriyle sınırlı kalmayıp uygulamaya da yeteri kadar ağırlık verilmesi gerektiğini de vurgulamışlardır.

Öğretici yeterliklerinin tamamında olduğu gibi pedagojik yeterlikler de hizmet öncesi, hizmet içi ve iş başında eğitimlerle gerçekleştirilmektedir. Bilgi üretim ve bilgiye erişimindeki imkân ve hız artışı düşünüldüğünde sürekli eğitim anlayışı ile öğretmen öğrenmesinin güçlendirilmesi ve öğretmenlerin/öğreticilerin çağı yakalaması sağlanmalıdır. Bu yüzden ikinci araştırma sorusunun cevabı aslında her zaman ve her yerde farkındalık ile kazanılmalı olmalıdır. Bir başka ifadeyle sınıf içinde öğrenciyi aktifleştirerek öğrenci öğrenmesini sağlamaya çalışan öğretmenin/öğreticinin sınıf dışında da aktif biçimde kendi öğrenmesi için çalışmalıdır.

Öğretmenlerin/öğreticilerin yeterliklerinin geliştirilmesine ilişkin süreçler mesleğe başlamadan önce alınan "hizmet öncesi" ve mesleğe başladıktan sonra alınan "hizmet içi" eğitim olmak üzere iki temel bölüme ayrılabilir.

\section{Hizmet Öncesi Eğitim}

Öğretici yeterliklerinin kazandırıldı̆̆ı temel program Türkçe öğreticileri için Türkçe Öğretmenliği ile Türk Dili ve Edebiyatı Öğretmenliği programlarıdır. Ancak pedagojik formasyon eğitimi gerçeği de göz ardı edilmemelidir. Niteliği tartışmalı olsa da bu öğretim sürecinde de alan bilgisi ile örtüşmenin sınırlı kaldığı dersler verilmekte ve pedagojik yeterlikler artırılmaya çalışılmaktadır. Yine her iki sürecin tamamlayıcı parçası olan öğretmenlik uygulamaları, stajlar da yine hizmet öncesi eğitimin bir parçasıdır. Öğreticilere pedagojik yeterliklerin kazandırıldığı ilk yer üniversitelerde lisans düzeyindeki eğitimlerdir. Bu eğitimler eğitim fakültelerinde eğitim-öğretim sürecinin tamamına yayılmışken pedagojik formasyon eğitimlerinde daha yoğun biçimde verilmektedir ki bu da ayrı bir eleştiri konusudur.

Türkçe öğreticileri için pedagojik yeterliklerin kazandırıldığı hizmet öncesi eğitimlerden biri de kurumların göreve kabulden sonra ancak göreve başlamadan önce verilen eğitimlerdir. Bu eğitimler sertifika programları, kurum kültürünü aktaran kültürleme süreçleri şeklinde tasarlanabilmektedir. Bu eğitimlerin süresi genelde birkaç hafta veya birkaç aydan ibarettir. Ancak öğreticilerin eğitim süreçleri işe başlamakla bitmez aksine öğretmeyi öğrenme sayesinde mesleki bir rutine döner, dönmesi beklenir.

\section{Hizmet lç̧i Ĕgitim}

Hizmet içi eğitim programları ana dili olarak Türkçe öğreticileri için ara tatil ve yaz tatillerindeki seminerler olarak planlanmakta ve düzenlenmektedir. Türkçeyi ikinci/yabancı dil olarak Türkçe öğretenlerin durumu ise kurumlarına göre değişkenlik göstermektedir. Bu kapsamda yabancı dil 
öğreticilerini istihdam eden Yunus Emre Enstitüsü ve Türkiye Maarif Vakfının özellikle yaz dönemlerinde hizmet içi eğitimler düzenlendiği bilinmektedir. İkinci dil olarak Türkçe öğreticisi olarak nitelenen TÖMER'lerdeki personelin hizmet içi eğitimi ise büyük oranda ihmal edilmekte ve bu tür programlar düzenlenmemektedir. Oysaki yansıtmacı yaklaşımlarla hem kurum içi hem de TÖMER'ler arası öğretim görevlisi değişim programları ve eğitimler ile kurumlar arası eğitim programları düzenlenebileceği düşünülmektedir. Özellikle büyükşehirlerdeki tecrübeli kurumların diğer TÖMER'lere standart sağlayıcı olarak fayda sağlaması mümkün görünmektedir. Üstelik bu süreç tek taraflı olamayacak standart sağlayıcı TÖMER'ler de özgün uygulamalar keşfedebilecektir. Ancak bunun için öncelikle TÖMER belgelerinin tam geçerliliği, eğitim süresi, ölçme-değerlendirme gibi temel alanlarda TÖMER'lerin temel standartları asgari oranda ve şeffaf biçimde işletiyor olması gerekmektedir.

\section{Tartışma ve Sonuç}

Ana dili olarak Türkçe öğretilen sınıflara dâhil olan iki dilli çocuklar ve taşıdıkları kültür, dil unsurları Türkçe öğretmenlerinin sahip olması gereken yeterlikleri de etkilemiştir. Daha çok ikinci/yabancı dil öğretim süreçlerinde dikkat edilmesi gereken pedagojik hassasiyetler mülteci öğrenci gerçeği ile ana dili olarak Türkçe öğreten öğretmenler için de ihtiyaç hâline gelmiştir. Türkiye'de doğan veya bir şekilde Türkiye vatandaşlığı alarak Türkiye vatandaşı olarak eğitim-öğretim hayatına başlayan mülteci çocuklar ana dili olarak Türkçe dersi alsalar da onlar için Türkçe ana dili değildir ve kaynak kültür Türk kültürü değildir. Bu noktada ana dili olarak Türkçe öğretmenlerinin de pedagojik alan bilgisini bu yönde güncellemesi en azından bu farkındalığı kazanması gerekmektedir. Çünkü ana dili olarak Türkçe öğretiminin temel unsuru olan öğrencilerde sesletim, anlamlandırma, derin yapıyı kavrama gibi sorunlar sınırlı iken mülteci öğrenciler için bu çözülmeyi bekleyen kronik bir sorun olabilmektedir. Bu noktada örnek vermek gerekirse; Türkçe öğretmeninin ana dili Arapça olan bir öğrencinin " $p$ " sesini zaman zaman veya başlangıçta hiç çıkartamamasını anlaşılamaz bir durum olarak karşılamaması için ikinci/yabancı dil öğretimine ilişkin alan bilgisine da sahip olması gerekmektedir.

Kurudayıoğlu ve Sapmaz (2016, s. 87)'ın belirttiği üzere ana dili, konuşma becerisi ile dinleme becerisi sayesinde ve herhangi bir eğitim süreci olmadan doğal biçimde edinilir. Ana dilinin edinimi sürecinde becerilerin edinilmesi sürecinde anne karnında başlayan dinleme ilk sırada yer alır. Ardından bilişsel ve fizyolojik hazırbulunuşluğun yeterli hâle gelmesi ve çevrenin de etkisiyle becerisinin edinildiğini belirtirler. Daha sonra ise öğretimin başlamasıyla birlikte okuma ve ardından yazma becerileri kazanıldı̆̆ını belirttikten sonra yabancı dilde sıranın farklılaştığını vurgularlar. Çünkü yabancı dil öğrenen kişinin ana dilinde bu becerilerin tamamını edindiği, kazandığı gerçeğine dikkat çekerek bu yüzden yabancı dil öğretiminde dört becerinin de aynı anda öğretildiğine dikkat çekerler.

Ancak yukarıda bahsedilen ana dili sınıflarındaki iki dilli mülteci öğrenciler daha karmaşık ve özel olarak yoğunlaşılması gereken bir alan oluşturmaktadır. Çünkü ana dili olarak Türkçenin öğretildiği sınıflarda özellikle ilkokul birinci sınıfta mülteci çocuklar ana dilinde okuma ve yazmayı öğrenmeden hedef dilde okuma yazma eğitimine başlamaktadırlar veya bu eş zamanlı biçimde yürütülmektedir. Yani bu hedef kitlede yetişkinlerin yabancı dil öğreniminde olduğu gibi dört beceri ana dilde edinilmiş değildir. Bu durumun sınıf içine birçok yansıması olacak ve öğreticilerin hem alan hem de pedagoji bilgisine ihtiyaç olacaktır.

Tüm bu durumlar Türkçe öğretmeni/öğreticisi yetiştirmenin ve pedagojik alan bilgisinin ne kadar önemli olduğunu göstermektedir. Öğretmen yetiştiren programlar da bu öneme uygun biçimde şekillendirilmelidir. Bu noktada pedagojik formasyon eğitimi adıyla dışarıdan verilen formasyon eğitiminin altını çizmek gerekir. Ana dilindeki öğreticiler gibi yabancı dil olarak Türkçe öğreticileri de pedagoji eğitimini bu programlarla alan eğitimine bütünleşmemiş bir yapıda alabilmektedir. Üstelik ana dilinde pedagoji eğitimi zorunluyken yabancı dilde böyle bir zorunluluk da bulunmamaktadır. Bu noktada Türkçeyi Türkiye'de ve Türkiye dışında öğretenler uluslararası bir öğrenci profiline hitap etmelerine rağmen bu önemli eğitim olmadan istihdam edilip çalıştırılabilmektedir. Oysaki tartışılması gereken pedagojinin gerekliliği değil, branşlara göre pedagoji eğitiminin geliştirilip çeşitlendirilmesi olmalıdır. 
Yabancı/ikinci dil öğreticisinin eğitim süreçlerinin ihtiyaçlara göre planlanması ve yönetilmesi gereklidir. Daha açık bir ifade ile yabancı/ikinci dil öğreticisinin yetiştirilmesi için özgün programlar açılmalı ve bu program diğer öğretmenlik branşlarında olduğu gibi pedagojik süreçlerle birlikte örülmelidir. Açılacak program bir lisans programı olmayabilir fakat alana özgü intisaslaşmayı sağlayacak standartları olan bir program olarak tasarlanmalıdır. Örneğin; öğretici yetiştirme enstitüsü gibi bir ada ve Türkçenin ikinci/yabancı dil olarak öğretimini icra edecek öğreticileri yetiştirme hüviyetine resmen yetkilendirilmiş bir şekilde sahip olabilir. Ancak daha efektif bir çözüm yolu şu şekilde açılabilir: Türkçeyi ana dili olarak öğretmek üzere öğretmen yetiştiren bölümlerin programlarında gerekli düzenlemeleri yapıp belli bir hazırbulunuşluk sağlandıktan sonra branşlaşmaya gidilmesini sağlamak ve öğretmenleri/öğreticileri çift diplomayla mezun etmek. Bu sayede her öğretici ana dili olarak Türkçe öğretmenliği diplomasının yanı sıra ikinci dil olarak Türkçe öğreticiliği, iki dillilere Türkçe öğreticiliği yabancı dil olarak Türkçe öğreticiliği gibi ikinci bir diplomayla daha mezun edilerek uzmanlaşanın ve profesyonel eğitimin temeli atılabilir. Tabii ki böyle bir düzenleme gerekli yasal düzenlemelerin de yapılması ile özel bir hak olarak tanınmalı ve söz konusu düzenleme yapıldıktan sonra gerekli diplomaya sahip olmayanların görevlendirilmemesi şeklinde hak sahiplerinin korunması sağlanmalıdır. Aksi takdirde pedagojik formasyon gerçeğinde olduğu gibi öğretmenlik mezunlarının yaşadığı durum yaşanabilir. Bu noktada diğer bir çözüm önerisi ise Türkçe öğretmenlerini/öğreticilerini yetiştirmede Finlandiya modeli sınama ve atama uygulanabilir.

Avrupa ülkelerinin öğretmen yetiştirme sistemleri kıyaslandığında, öğretmen yetiştirme programlarında farklılıklar olduğu göze çarpmaktadır. Almanya ve Fransa öğretmen yetiştirme programlarında uzmanlık alan bilgisine daha çok önem vermektedir. Finlandiya öğretmenlerin pedagojik bilgilerini ön plana koymaktadır. İngiltere öğretmenin mesleki bilgisine daha çok ağırlık vermektedir (Orhan, Gökhan 2015, s. 48).

Finlandiya'da dört yıllık temel öğretmenlik eğitiminin üzerine iki yıl süren lisansüstü eğitimi tamamlama şartı bulunmaktadır. Bu şartı yerine getiren mezunlar merkezi atama ile değil ihtiyaca göre seçilip görevlendirilmektedir. Bu model yasal düzenleme ile şart hâline getirildiğinde aslında Türkçenin ikinci/yabancı dil öğreticileri için gerçekteki durum yasalarla standartlaştırılmış olacaktır. Dört yıllık Türkçe öğretimi mezunları ana dili olarak Türkçe öğretmenliği diplomasını aldıktan sonra seçecekleri branşa göre lisansüstü eğitimleri ile branş uzmanlığı elde edebilecektir.

Bir diğer diğer yol ise ana dili olarak Türkçe haricindeki branş uzmanlarının yetiştirilmesi özel olarak yapılandırılacak bir kurumun sorumluluğuna verilerek İngilizce öğreticilerinin yetiştirilme süreçlerine benzer bir yapı ile izlenebilir. Akademisyen, uzman ve yetkililer bu noktaya gelindiğinde gerekli müzakereler ile en doğru eylem planını oluşturacaktır ancak önemli olan standartlaşma sorununun da çözümüne katkı sağlayacak bu adım biran evvel atılması olacaktır.

Öğrenci üssü olmayı hedefleyen ve kültürel diplomasiye giderek daha çok önem veren Türkiye'de istihdam sorunu oluşturmayacak derecede Türkçe öğrenci arzı oluşturulduğunda özel bir lisans programının açılması da öngörülebilir bir durum. Nitekim Şahin, Kurudayıoğlu, Tunçel ve Öztürk (2013, s.44), Türkçenin yabancı dil öğretimini üstelenen öğretim görevlilerinin, okutmanların eğitildiği Türkçe Eğitimi bölümlerindeki programlarda "yabancılara Türkçe öğretimi", "yabancılara Türkçe öğretiminde yöntem" derslerinin farkındalık sağladığına ve temel bilgi birikimini oluşturduğuna vurgu yapar. Ancak yüksek lisansı olan bu alanın lisans programının da açıımasının gerekliliğine de dikkat çeker.

Eğitimde kalitenin artması için öğreticilere yapılan yatırımların artırılması gerekir. Türkçe öğreticilerinin niteliklerimi artırmak ve dünya dillerindeki iyi uygulamaların Türkçede de çoğaltılmasını sağlayacaktır. Bunun için öğreticilerin yeterliklerinin geliştirilmesi ve bu süreçlerin standartları olan süreçlerle gerçekleştirilmesi gerekmektedir. Daha net bir ifadeyle duruma göre çözümler üretmek ve bu şekilde eğitimler düzenlemek yerine, çözüme uygun durumlar, süreçler ve kurumlar oluşturularak dünya standartlarında ve akredite edilebilir, edilmiş yapıların oluşturulması gerektiği düşünülmektedir. Bunun için hâlihazırda Türkçe öğretmeni yetiştiren ana bilim dallarındaki akademisyenleri hem teorik hem de uygulama bilgisi anlamında bunu yapmaya yetecek düzeyde olduğu düşünülmektedir. Bu noktada tıpkı ana dili öğretmenleri için MEB'e bağlı okullardaki zorunlu staj sürecinin TÖMER, YEV ve TMV gibi kurumlarla diğer Türkçe öğreticilerinin yetiştirilmesi sürecine 
dâhil edilmesi hem eğitim programlarının niteliğini artıracak hem de adı geçen kurumların hizmet öncesi ve hizmet içi eğitim sürçlerindeki zaman, emek ve ekonomik maliyetlerini düşürecektir. Son olarak, bu kurumların müşterek hareket edebilmesi öğretici yeterliklerinin ve pedagojik yeterliklerin kazandırılması sürecinde sahadan alınacak sürekli ve düzenli bilgilerle programların da kuvvetlendirilebileceği böylelikle pedagojik yeterliklerin uygulamayla iç içe geliştirilebileceği söylenebilir.

\section{Araştırma ve Yayın Etiği}

Bu çalışmada "Yükseköğretim Kurumları Bilimsel Araştırma ve Yayın Etiği Yönergesi" kapsamında uyulması belirtilen tüm kurallara uyulmuştur. Yönergenin ikinci bölümü olan "Bilimsel Araştırma ve Yayın Etiğine Aykırı Eylemler" başlığı altında belirtilen eylemlerden hiçbiri gerçekleştirilmemiştir.

\section{Yazarların Katkı Oranı}

Makale tek yazarlı olup, adı geçen yazar tarafından hazırlanmıştır.

\section{Çıkar Çatışması}

Çıkar çatışması teşkil edebilecek durum ve ilişkiler bulunmamaktadır.

\section{Kaynaklar}

Aksoy, T. ve Temizyürek, F. (2016). Analysis on speacial field competencies of Turkish teachers. Mehmet Akif Ersoy Üniversitesi Eğitim Fakültesi Dergisi, 1(38), 103-117.

Bourgonje. P. ve Tromp. R. (2011). Quality educators: An international study of teacher competences and standards. Netherlands: Education International and Oxfam Novib.

Güleç, I. ve Okur, A. (2015, Haziran) Türkçe öğretmeni yeterliği. III. Türkçe Eğitimi Bölümleri Çalıştayı, Sakarya: Sakarya Üniversitesi Eğitim Bilimleri Enstitüsü Yayınları, 15.

Hacettepe Üniversitesi. (2017). Türkiye'de öğretmen eğitimi ve istihdamı mevcut durum ve öneriler. Ankara.

Kurudayıŏlu, M, Çelik, G. (2013). Türkçe öğretmeni adaylarının okumaya ve okuma eğitimine ilişkin özyeterlik algıları. Uşak Üniversitesi Sosyal Bilimler Dergisi, 6(4). Erişim adresi: https://dergipark.org.tr/tr/pub/usaksosbil/issue/21640/232596

Kurudayıŏlu, M. ve Kana, F. (2013). Türkçe öğretmeni adaylarının dinleme becerisi ve dinleme eğitimi özyeterlik algıları. Mersin Üniversitesi Eğitim Fakültesi Dergisi, 9(2), 245-258. Erişim adresi: https://dergipark.org.tr/tr/pub/mersinefd/issue/17383/181611

Kurudayıoğlu, M. ve Sapmaz, S. (2016). Yabancı dil olarak Türkçe konuşma öğretimine dair öğretmen bilişleri. Zeitschrift für die Welt der Türken, 8(3), 85-102.

Loughran, J. Keast, S. ve Cooper, R. (2016). International handbook of teacher education (John Loughran, ary Lynn Hamilton Ed.). Singapore: Springer.

MEB. (2017). Öğretmenlik mesleği genel yeterlikleri. Öğretmen Yetiştirme Genel Müdürlüğü, Ankara.

Mete, F. ve Asar, A. (2014). Üniversite programlarında yabancı dil olarak Türkçe öğretmeni alan yeterliklerinin araştırılması. Hacettepe Üniversitesi Yabancı Dil Olarak Türkçe Araştırmaları Dergisi, (1), 121-142.

Mishra, P. ve Koehler, M. J. (2006). Technological pedagogical content knowledge: A framework for integrating technology in teachers' knowledge. Teachers College Record, 108(6), 1017-1054.

Orhan, G. (2015). Öğretmenlerin üst bilişsel pedagojik anlayışları ölçeğinin Türkçeye uyarlanması: Geçerlik ve güvenirlik çalışması (Yayımlanmamış yüksek lisans tezi). Gaziosmanpaşa Üniversitesi Eğitim Bilimleri Enstitüsü, Tokat.

Peker, K. (2010). Kamu kurum ve kuruluşlarında hizmet içi eğitim ve yöntemleri. Mevzuat Dergisi, 13(56), 1-16. Erişim adresi: https://www.mevzuatdergisi.com/2010/12a/02.htm adresinden 20 Aralık 202000.41 tarihinde alınmıştır.

Richards, J. C. ve B. Anne (2009). The Cambridge guide to second language teacher education. New York: Cambridge University Press. 
Richards, J. C. (2008). Second language teacher education today. RELC Journal 39(2), 158-177.

Richards, J. C. (2011). Competence and performance in language teaching. New York: Cambridge University Press.

Shulman, L. (1986). Pedagojik alan bilgisi: Öğretmenlerin konu konusu, pedagoji, öğrenciler ve öğrenme ortamlarına entegrasyonu. Educational Researcher, 15, 4-14. Erişim adresi: https://narst.org/research-matters/pedagogical-content-knowledge

Shulman, L. (1987) Knowledge and teaching: Foundations of the new reform. Harvard Educational Review, 57, 1-22.

Şahin, A. (2018). Yabancı dil olarak Türkçe öğretimi kuramlar, yaklaşımlar, etkinlikler. Ankara: Pegem Akademi.

Şahin, Ç., Kurudayıoğlu, M., Tunçel, H. ve Öztürk, Y. A. (2013). Türkçe öğretmeni adaylarının lisans düzeyinde verilen yabancılara Türkçe öğretimi (YTÖ) dersine yönelik özyeterlik algıları. Ana Dili Eğitimi Dergisi, 1(2), 36-45.

TED (2009). Öğretmen yeterlikleri. Ankara: Adım Okan Matbaacılık.

TYYÇ. (2020). Türkiye yükseköğretim yeterlikler çerçevesi 2020. Erişim Adresi: http://tyyc.yok.gov.tr/?pid=38

Yavuz S. (2013) Yabancı dil Türkçe öğreten İngilizce öğretmenleri ile bir durum incelemesi: Türkçe balta girmemiş orman. Turkish Studies - International Periodical For The Languages, Literature and History of Turkish or Turkic, 8(8), 1463-1474.

Yıldırım, A. ve Şimşek, H. (2006). Sosyal bilimlerde nitel araştırma yöntemleri. Ankara: Seçkin Yayıncilık.

YÖK. (2018). Öğretmen yetiştirme lisans programları. Erişim Adresi: https://www.yok.gov.tr/Documents/Kurumsal/egitim_ogretim_dairesi/Yeni-OgretmenYetistirme-Lisans-Programlari/AA_Sunus_\%200nsoz_Uygulama_Yonergesi.pdf

\section{Extended Abstract}

\section{Introduction}

Learners' successful learning and acquisition of the target language presented by teachers depends on the attitudes, approaches, and behaviors of teachers. These attitudes, approaches, and behaviors are directly linked to the development of technology, pedagogy, and field knowledge as well as teachers' ability to employ them. Field knowledge, undoubtedly, appears as one of the core competencies that teachers should have. Today, the tools used in the teaching of the target language regard technology as an indispensable component in the education process. However, the answer to "how to transfer?" this crucial information to learners is related to pedagogy. Pedagogy has not yet been studied sufficiently in teaching Turkish as a second/foreign language. As a matter of fact, the pedagogical competencies of teachers in foreign or second language teaching have almost never been studied, and even the number of postgraduate studies in this field of pedagogy is limited.

The majority of Turkish teachers graduate from Turkish Teacher education and Turkish Literature departments. The field of Turkish language teaching is to be divided based on the context of instruction as teaching Turkish as the mother tongue, as a second/foreign language, and to bilingual students. As such, pedagogical competencies of those teachers should not only be organized in compliance with general pedagogical knowledge, but also in consideration of the requirements particular to their fields. Although the competencies of Turkish teachers have been defined in terms of general knowledge and skills areas, in the contemporary approaches, competencies should be defined both generally and field-specifically. Accordingly, the concept of technological pedagogical content knowledge will be discussed specifically for Turkish teachers. Within the scope of this study, teacher competencies were also examined and suggestions were given for the education of different types of Turkish teachers.

The learning-teaching process focused on the intersection of field-pedagogy with the approach developed by Shulman (1986) and included technology as per contemporary requirements. The studies pioneered by Mishra and Koehler (2006) led to the definition of technological pedagogical content knowledge. The study titled General Competencies for the Teaching Profession 
was published as part of the Basic Education Support Project and carried out under the auspices of the Ministry of National Education General Directorate of Teacher Training and Education is important in establishing a national standard for these concepts. The Ministry of National Education and Higher Education Council continued to carry out studies on the General Competencies of the Teaching Profession, and the Ministry of National Education updated the General Competencies for the Teaching Profession in 2011. The curricula in the education faculties were updated this way. While those efforts were in progress, a book titled "Teacher Competencies" by the Turkish Education Association (2009) was also published on the issue.

\section{Method}

This study was designed as a case study. The most basic feature of a qualitative case study is to examine one or more cases in depth. Factors (environment, individuals, events, processes, etc.) related to a case are investigated through a holistic approach to reveal how they affect the case and how they are affected by it (Yıldırım \& Şimşek, 2006, p.77). Descriptive survey model was used in the study.

In the light of the international and national criteria and studies, answers to the following questions were sought:

1. What are the pedagogical competencies that Turkish teachers/instructors are to possess?

2. Where, when, and how should pedagogical competencies be acquired?

\section{Results and Discussion}

The competencies Turkish teachers should possess have been determined in general terms in the Turkish Higher Education Qualifications Framework and MoNE Teacher Competencies definitions, and then, as in every branch, these have provided the basis for the determination of the special field competencies of Turkish teachers. However, the subject of pedagogical content knowledge and pedagogical competencies that Turkish teachers should possess have not been studied specifically in the context of teaching Turkish as a second/foreign language. Within the scope of the study, national and international literature was reviewed, and a list of pedagogical competencies was created for Turkish teachers. Thus, it is believed that studies on pedagogical competence and self-efficacy may be carried out, and the quality of education can be improved.

Where, when, and how these competencies could be acquired by teachers and pre-service and in-service training of them were discussed. Some of which are given below:

The education of Turkish as a second/foreign language teachers should be planned and managed based on needs. Specific programs should be established for the training of teachers of Turkish as a second/foreign language, and the program should include the pedagogical knowledge considered essential in other fields.

After making the necessary arrangements in the programs that train Turkish teachers, it may be an alternative solution to allow the students to major in teaching Turkish as a second/foreign language or do a double degree. This way, in addition to a diploma of teaching Turkish, every prospective teacher can have a second diploma, and the foundations of diversified professional education may thus be laid.

Teaching practice courses for the new teacher education programs should also be carried out in the MoNE schools and may start in the third year of study in the current program, and a second internship can be done in the fourth year by cooperating with institutions such as Turkish Teaching and Research Centers (TÖMER), the Yunus Emre Institute (YEE) and the Turkish Education Foundation (TMV). 